\title{
Digital droplet PCR for precise quantification of human T-lymphotropic virus 1 proviral loads
}

\author{
Giovanna S Brunetto , Raya Massoud, Joan Ohayon, Kaylan Fenton, Irene Cortese, Steven Jacobson \\ From 16th International Conference on Human Retroviruses: HTLV and Related Viruses \\ Montreal, Canada. 26-30 June 2013
}

Elevated HTLV-1 proviral load (PVL) is thought to be the major risk factor for developing HAM/TSP in HTLV-1 infected subjects, and a high cerebrospinal fluid (CSF) to peripheral blood mononuclear cells (PBMCs) PVL ratio might be diagnostic of the condition. However, the standard method for quantification of HTLV-1 PVL, Real time PCR, has multiple limitations: the inter-assay variability increases at low PVL and low cell numbers in CSF often precludes accurate quantification. Thus, we are evaluating a novel technique, Digital Droplet PCR (ddPCR), as a potentially more reliable tool. For ddPCR, DNA samples are partitioned into thousands of nanoliter -sized droplets, amplified on a thermocycler, queried for fluorescent signal and normalized to a housekeeping gene. Due to the high number of DNA molecules and number of "independent" events (droplets), Poisson algorithms are used to determine absolute copy numbers and are independent of a standard curve. Our results suggest that ddPCR is very accurate: Intraassay variability evaluated by calculating the coefficient of variation of ten replicates of three samples of DNA in three different ranges of PVL (low $<5 \%$, medium $5-10 \%$, and high $>10 \%$ ) was $13.0 \%, 7.1 \%$ and $9.5 \%$, respectively. Interassay variability, was evaluated by calculating the $\mathrm{CV}$ of duplicates of PVL from three independent runs and three independent extractions was $4.5 \%$ with a standard deviation of 0.008 . Additionally, ddPCR is reliable in quantifying PVL in the CSF where we have confirmed and extended previous observations of increased HTLV-I PVL in CSF of HAM/TSP compared to the periphery.

Published: 7 January 2014

Viral Immunology Section, Neuroimmunology Branch, National Institutes of Neurological Disorders and Stroke, Bethesda, MD, USA
doi:10.1186/1742-4690-11-S1-P13

Cite this article as: Brunetto et al.: Digital droplet PCR for precise quantification of human T-lymphotropic virus 1 proviral loads. Retrovirology 2014 11(Suppl 1):P13.
Submit your next manuscript to BioMed Central and take full advantage of:

- Convenient online submission

- Thorough peer review

- No space constraints or color figure charges

- Immediate publication on acceptance

- Inclusion in PubMed, CAS, Scopus and Google Scholar

- Research which is freely available for redistribution
() Biomed Central

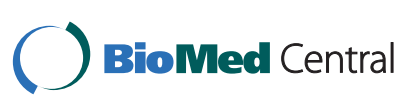

